\title{
Academic-Related Perceptions, Beliefs, and Strategies of Undergraduate Agricultural Students
}

\author{
S. Jordan ${ }^{1}$, C. T. Stripling ${ }^{2}$, C. Boyer ${ }^{3}$, C. A. Stephens ${ }^{4}$, N W. Conner ${ }^{5}$
}

\begin{abstract}
Students' academic-related perceptions, beliefs, and strategies are fundamental elements that influence teaching and learning within colleges of agriculture. This study investigated students' academic efficacy, academic self-handicapping, and skepticism about the relevance of school for future success at the University of Tennessee's Herbert College of Agriculture. The students were academically efficacious, rarely self-handicapped, and did not doubt the relevance of their degree. In addition, a low negative association was found between academic efficacy and self-handicapping, a negligible relationship was found between academic efficacy and skepticism about the relevance of school for future success, and a moderate relationship was found between academic selfhandicapping and skepticism about the relevance of school for future success. Therefore, instructors are encouraged to move past traditional lecture-based instruction and challenge their students at higher cognitive levels, which will allow students to realistically explore the complexities of agriculture. Furthermore, academic self-handicapping may be an indicator of lower academic efficacy and/or skepticism about the relevance of a student's degree. Future research should further explore these relationships
\end{abstract}

\section{Keywords}

academic efficacy; self-handicapping; skepticism; learning environment; social cognitive theory

1. Samantha Jordan, Graduate Student, The University of Tennessee, https://orcid.org/0000-0003-1192-1967

2. Christopher T. Stripling, Associate Professor \& Interim Department Head, The University of Tennessee, https://orcid.org/0000-0002-5045-3492

3. Christopher Boyer, Associate Professor, The University of Tennessee, https://orcid.org/0000-0002-1393-8589

4. Carrie A Stephens, Professor, The University of Tennessee, https://orcid.org/0000-0001-5592-2377

5. Nathan W. Conner, Associate Professor, University of Nebraska-Lincoln, https://orcid.org/0000-0003-0063-4110 


\section{Introduction and Problem Statement}

Rapid change in the world has unleashed extraordinary challenges and opportunities creating a sense of urgency concerning the fields of agricultural sciences and natural resources (National Research Council, NRC, 2009). Furthermore, sustaining the global enterprise that supports production of agricultural products has generated a requirement for agriculture graduates to be able to work in an evolving workplace (NRC, 2009). Accordingly, university academic programs need to be revived and restructured to sustain the continuous revolving door of expectations that accompany evolving times (NRC, 2009) and the shortage of agricultural baccalaureate graduates (Goecker, Smith, Fernandez, Ali, \& Goetz, 2015). Graduates with expertise in the agricultural sciences are crucial to the Unites States' ability to address national and global priorities (Goecker, et al., 2015), and addressing both societal and industry challenges will require a better understanding of the complexities of agriculture teaching and learning (NRC, 2009; Stripling \& Ricketts, 2016), including variables related to the educator, learner, and the cultural, social, and physical learning environment (National Academies of Science, 2018). According to the National Academies of Science (2018), effective instruction depends on an understanding of this complex interplay among educator, learner, and environmental variables.

To that end, this study seeks to add to the limited knowledge of undergraduate agriculture students' academic efficacy, academic self-handicapping, and skepticism about the relevance of school for future success, which are fundamental elements that impact learner engagement in academic tasks. The results of this study may provide valuable insight into improving undergraduate programs in agricultural and natural resources and be relevant to university educators and administrators by developing a deeper understanding of the above factors and how they impact the educational environment.

\section{Theoretical and Conceptual Framework}

Bandura's (1986) social cognitive theory explicates cognitive developmental changes experienced by people during a lifetime and provides a foundation for social learning. According to Bandura (1997), human functioning occurs "within an interdependent causal structure involving triadic reciprocal causation" (p. 6), in which the environment, behavior, and internal personal factors influence one another bidirectionally. The determinates can unequally interact and influence one another over time, and the influences and reciprocal effects may not occur simultaneously, suggesting each person maintains the ability to both shape and redirect their own experiences (Bandura, 1986; Bandura, 1997). For this study, the behaviors of interest are academic performance and self-handicapping. The personal factors under investigation are academic self-efficacy and skepticism about the relevance of school for future success. The environment in which these behaviors and personal factors are observed is the Herbert College of Agriculture.

\section{Behavior: Academic Performance and Self-Handicapping}

Multiple facets affect academic performance including quality of academic feedback or lack thereof (Bandiera, Larcinese, \& Rasul, 2015; Stinebrickner \& Stinebrickner, 2013); prior 
learning, life experiences, and ongoing performance (Martin, Wilson, Liem \& Ginns, 2013); psychological needs (Osterman, 2000); a learner's cultural, social, cognitive, and biological context and interest, motivation and ability to regulate learning; educator's knowledge of learner development and choice of pedagogical strategies and assessments; the social and physical learning environment (National Academy of Sciences, 2018); and so forth.

Self-handicapping involves creating impediments to inhibit or explain performance (Berglas \& Jones, 1978; Gadbois \& Sturgeon, 2011; Zuckerman, Kieffer, \& Knee 1998). Academic selfhandicapping is an action or choice (e.g., procrastination, overcommitting, consuming drugs/alcohol before an exam, etc.) that improves an opportunity to externalize one's failure, and yet still internalize success (Berglas \& Jones, 1978). Chronic self-handicapping may negatively affect academic outcomes and accomplishments (Schwinger, Wirthwein, Lemmer, \& Steinmayr, 2014) and over time self-efficacy (Arazzini \& De George-Walker, 2014).

\section{Personal Factors: Academic Self-Efficacy and Relevance of School}

Academic self-efficacy is a student's belief in their own ability to complete an academic skill or task, and this belief influences effort, persistence, use of metacognitive and self-regulatory strategies, and academic achievement (Pintrich \& Zusho, 2007). Also, academic self-efficacy positively influences socio-cognitive processes and is a robust predictor of undergraduate academic performance (Putwain, Sander \& Larkin, 2013). Self-efficacy can be influenced through mastery and vicarious experiences, verbal persuasion that one possesses or does not possess a capability, and physiological and affective states (Bandura, 1997).

In regards to skepticism about the relevance of school for future success, individuals with a future time perspective tend to place greater emphasis on success "via goal-directed behavior, giving greater attention to environmental cues, and engaging in a greater number of activities to achieve these goals" (Murrel \& Mingone, 1994, p. 4). However, Humphreys and Davenport (2005) found that students perceived specific requirements of the college curriculum derailed their self-development and created a distraction from major coursework. Perceptions impact college students' prescribed value and relevance of coursework to their career or life (Pintrich \& Zusho, 2007). Furthermore, students are more apt to engage in learning when they value the learning experience (Deci, Vallerand, Pelletier, \& Ryan, 1991).

\section{Environment: Herbert College of Agriculture at the University of Tennessee}

The Herbert College of Agriculture prepares students for careers in agricultural, environmental, life, and social sciences and seeks to enhance educational efforts in order to sustain economic strength, food security, and health; in addition to safeguarding and improving our natural environment (Herbert College of Agriculture, 2013). The Herbert College of Agriculture is operating in an era in which colleges of agriculture have been "challenged to transform their role in higher education and their relationship to the evolving global food and agricultural enterprise" (NRC, 2009, p. 1). 


\section{Purpose}

The purpose of this study was to investigate undergraduate agricultural students' academicrelated perceptions, beliefs, and strategies. The following objectives framed this study:

1. Describe the academic efficacy of undergraduate students in the Herbert College of Agriculture at the University of Tennessee.

2. Describe the academic self-handicapping of undergraduate students in the Herbert College of Agriculture at the University of Tennessee.

3. Describe the skepticism about the relevance of school for future success of undergraduate students in the Herbert College of Agriculture at the University of Tennessee.

4. Describe the relationship between academic efficacy, academic self-handicapping, and skepticism about the relevance of school for future success.

\section{Methods}

The research design was descriptive survey research, and the target population was undergraduate students in the Herbert College of Agriculture $(N=1,286)$ at the University of Tennessee. The sample was a convenience sample of 303 students or $24 \%$ of the target population and consisted of 88 males and 215 females. The average age of the sample was 21.6 years old $(S D=4.73)$ with a minimum and maximum of 18 and 49 years old, respectively. The class level of the sample was $20 \%$ freshman, $18 \%$ sophomores, $28 \%$ juniors and $34 \%$ seniors. The mean grade point average was $3.3(S D=.68)$ on a four-point scale. Additionally, the sample was compared to the known demographic variables of ethnicity, class level, and gender and was found to be representative based on ethnicity and class level. However, the sample was skewed towards females, and was weighted based on the population parameter to create a representative sample.

Data were collected using a researcher-developed questionnaire that consisted of the following: six demographic questions and Midgley et al.'s (2000) five item Academic Efficacy Scale, six item Academic Self-Handicapping Strategies Scale, and the six item Skepticism About the Relevance of School for Future Success Scale. Based on six cognitive interviews, changes were made to improve the clarity of the questionnaire's directions, and minor wording changes to the academic efficacy and self-handicapping scales to fit the context of the study. For example, I'm certain I can master the skills taught in class this year was changed to I'm certain I can master the skills taught in my classes this year, and Even if I do well in school, it will not help me have the kind of life I want when I grow up was changed to Even if I do well in school, it will not help me have the kind of career I want when I graduate. Midgley et al. reported Cronbach's alpha coefficients for academic efficacy as .78, .84 for the academic self-handicapping strategies, and .83 for skepticism about the relevance of school for future success, and the post-hoc reliabilities for each construct were $0.91,0.87$, and 0.88 , respectively. The scales used a rating scale of $1=$ not at all true, 3 = somewhat true, 5 = very true.

Data were collected using the online Qualtrics Survey software. The questionnaire was sent to the undergraduate students using their university email accounts, and Dillman, Smyth, and 
Christian's (2014) procedures for implementing web surveys guided the multiple contacts made. Four emails were sent through the Qualtrics Survey software approximately one week apart to all Herbert College of Agriculture students. The first email was sent to inform the entire population of the study. The second email contained the link to the survey and the online informed consent. The third and fourth emails were sent as a reminder of the opportunity to participate in the study and both contained the link to the survey.

Descriptive statistics were used to summarize demographic information. Summated means were calculated for each of the three aforementioned scales. Frequencies and percentages were also calculated for each item of the scales, and Pearson correlations were used to determine the associations between academic efficacy, academic self-handicapping, and skepticism about the relevance of school for future success. Davis' (1971) terminology was used to indicate the magnitude of the correlations. Correlations from .01 to .09 are negligible, .10 to .29 are low, .30 to .49 are moderate, .50 to .69 are substantial, .70 to .99 are very strong, and a correlation of 1.00 is perfect.

The findings of the study may not be generalizable beyond the target population of undergraduate students in Herbert College of Agriculture at the University of Tennessee. Therefore, readers should use caution when generalizing the results of this study unless data confirms the target population of this study is representative of other populations of undergraduate agricultural students.

\section{Findings}

\section{Objective 1: Describe the Academic Efficacy of Undergraduate Students in the Herbert College of Agriculture at the University of Tennessee.}

A majority agreement was reached on all academic efficacy items (Table 1). The summated mean for academic efficacy was $4.16(S D=0.04)$, which indicates the undergraduate students are academically efficacious.

Table 1

Summary of Student Responses on the Academic Efficacy Items

\begin{tabular}{|c|c|c|c|c|c|}
\hline & 1 & 2 & 3 & 4 & 5 \\
\hline Items & $\%$ & $\%$ & $\%$ & $\%$ & $\%$ \\
\hline Even if the classwork is hard, I can learn it. & 1.3 & 3.4 & 12.7 & 36.7 & 46.0 \\
\hline $\begin{array}{l}\text { I can do almost all of the work in my classes if I don't } \\
\text { give up. }\end{array}$ & 0.7 & 1.8 & 12.1 & 35.3 & 50.1 \\
\hline $\begin{array}{l}\text { I'm certain I can figure out how to do the most difficult } \\
\text { classwork. }\end{array}$ & 1.1 & 5.5 & 21.8 & 37.6 & 34.1 \\
\hline I can do even the hardest work in my classes if I try. & 0.7 & 4.0 & 18.1 & 38.0 & 39.1 \\
\hline $\begin{array}{l}\text { I'm certain I can master the skills taught in my classes } \\
\text { this year. }\end{array}$ & 1.3 & 2.6 & 19.5 & 35.4 & 41.2 \\
\hline
\end{tabular}

Note. $1=$ not at all true, $3=$ somewhat true, $5=$ very true. 


\section{Objective 2: Describe the Academic Self-handicapping of Undergraduate Students in the Herbert College of Agriculture at the University of Tennessee.}

A majority of undergraduate students strongly disagreed with five of the six academic selfhandicapping items and disagreed with the remaining self-handicapping item (Table 2). The summated mean for academic self-handicapping was $1.66(S D=0.04)$, which indicates the undergraduate students do not or rarely self-handicap.

Table 2

Summary of Student Responses on Academic Self-Handicapping Items

\begin{tabular}{|c|c|c|c|c|c|}
\hline Itomc & $\begin{array}{l}1 \\
o\end{array}$ & $\begin{array}{l}2 \\
o\end{array}$ & $\begin{array}{l}3 \\
0\end{array}$ & $\begin{array}{l}4 \\
o\end{array}$ & $\begin{array}{l}5 \\
0\end{array}$ \\
\hline $\begin{array}{l}\text { Items } \\
\text { Some ctudentc nurnocolv got involved in lotc of activitioc }\end{array}$ & $\frac{1}{583}$ & $\%$ & $\frac{\%}{152}$ & $\frac{\%}{25}$ & $\frac{1}{0}$ \\
\hline $\begin{array}{l}\text { Some students purposely get involved in lots of activities. } \\
\text { Then if they don't do well on their classwork, they can say } \\
\text { it is because they were involved with other things. How } \\
\text { true is this of you? }\end{array}$ & 58.3 & 22.6 & 15.3 & 3.5 & 0.3 \\
\hline $\begin{array}{l}\text { Some students purposely don't try hard in class. Then if they } \\
\text { don't do well, they can say it is because they don't try. } \\
\text { How true is this of you? }\end{array}$ & 72.5 & 11.8 & 11.1 & 2.8 & 1.7 \\
\hline $\begin{array}{l}\text { Some students fool around the night before a test. Then if } \\
\text { they don't do well they can say that is the reason. How } \\
\text { true is this of you? }\end{array}$ & 61.0 & 21.0 & 12.0 & 3.8 & 2.3 \\
\hline $\begin{array}{l}\text { Some students put off doing their classwork until the last } \\
\text { minute. Then if they don't do well on their classwork, they } \\
\text { can say that this is the reason. How true is this of you? }\end{array}$ & 40.0 & 30.0 & 20.5 & 8.1 & 1.4 \\
\hline $\begin{array}{l}\text { Some students let their friends keep them from paying } \\
\text { attention in class or from doing their homework. Then if } \\
\text { they don't do well they can say their friends kept them } \\
\text { from working. How true is this of you? }\end{array}$ & 65.4 & 21.6 & 9.4 & 2.9 & 0.7 \\
\hline $\begin{array}{l}\text { Some students look for reasons to keep them from studying } \\
\text { (not feeling well, having to help their parents, taking care } \\
\text { of a brother or sister, etc.). Then if they don't do well on } \\
\text { their classwork, they can say this is the reason. How true } \\
\text { is this of you? }\end{array}$ & 57.4 & 25.0 & 13.6 & 3.3 & 0.7 \\
\hline
\end{tabular}

Note. 1 = not at all true, $3=$ somewhat true, $5=$ very true.

\section{Objective 3: Describe the Skepticism About the Relevance of School for Future Success of Undergraduate Students in the Herbert College of Agriculture at the University of Tennessee.}

A majority of undergraduate students strongly disagreed with four of the six skepticism about the relevance of school for future success items and disagreed with one skepticism item. The remaining item, getting good grades in school won't guarantee that I will get a good job when I graduate, had mixed responses (Table 3). The summated mean for skepticism about the 
relevance of school for future success was $2.00(S D=0.04)$, which indicates the undergraduate students were not skeptical about the relevance of their degree from the Herbert College of Agriculture.

Table 3

Summary of Student Responses on the Skepticism About the Relevance of School for Future Success Items

\begin{tabular}{|c|c|c|c|c|c|}
\hline & 1 & 2 & 3 & 4 & 5 \\
\hline Items & $\%$ & $\%$ & $\%$ & $\%$ & $\%$ \\
\hline $\begin{array}{l}\text { Even if I am successful in school, it won't help me fulfill } \\
\text { my dreams. }\end{array}$ & 57.4 & 21.0 & 14.1 & 5.1 & 2.5 \\
\hline $\begin{array}{l}\text { My chances of succeeding in a career don't depend on } \\
\text { doing well in school. }\end{array}$ & 55.3 & 20.5 & 17.0 & 4.2 & 3.0 \\
\hline $\begin{array}{l}\text { Doing well in school doesn't improve my chances of } \\
\text { having a good career when I graduate. }\end{array}$ & 59.5 & 22.3 & 10.3 & 6.9 & 1.0 \\
\hline $\begin{array}{l}\text { Doing well in school won't help me have a satisfying } \\
\text { career when I grow up. }\end{array}$ & 63.6 & 21.9 & 9.3 & 2.4 & 1.3 \\
\hline $\begin{array}{l}\text { Getting good grades in school won't guarantee that I } \\
\text { will get a good job when I graduate. }\end{array}$ & 8.8 & 12.5 & 34.7 & 21.8 & 22.2 \\
\hline $\begin{array}{l}\text { Even if I do well in school, it will not help me have the } \\
\text { kind of career I want when I graduate. }\end{array}$ & 49.6 & 26.6 & 18.0 & 4.5 & 1.4 \\
\hline
\end{tabular}
Note. 1 = not at all true, $3=$ somewhat true, $5=$ very true.

\section{Objective 4: Describe the Relationship between Academic Efficacy, Academic Self-handicapping, and Skepticism About the Relevance of School for Future Success.}

As shown in Table 4, academic efficacy was negatively related with academic self-handicapping and positively related to skepticism about the relevance of school for future success. Skepticism about the relevance of school for future success and academic self-handicapping were also positively related. In addition, a low negative association was found between academic efficacy and self-handicapping $(r=-.25)$. A negligible relationship was found between academic efficacy and skepticism about the relevance of school for future success $(r=.03)$, and a moderate relationship was found between academic self-handicapping and skepticism about the relevance of school for future success $(r=.33)$. 
Table 4

Correlations for Academic Efficacy, Academic Self-Handicapping, and Skepticism

\begin{tabular}{lccc}
\hline Variables & & Academic Self- & \\
& Academic Efficacy & handicapping & Skepticism \\
\hline Academic Efficacy & - & - & - \\
Academic Self-Handicapping & -0.25 & - & - \\
Skepticism & 0.03 & 0.33 & - \\
\hline
\end{tabular}

\section{Conclusions, Discussion, and Recommendations}

The undergraduate students in the Herbert College of Agriculture at the University of Tennessee are academically efficacious and do not or rarely academically self-handicap. Being academically efficacious and not practicing academic self-handicapping should exert a positive influence on the undergraduate students' academic behaviors and internal personal factors and the environment of the Herbert College of Agriculture (Bandura, 1986, 1997). This is encouraging, since academic efficacy mediates achievement gains (Putwain et al., 2013; Schunk, 2012), and those who academically self-handicap are seeking ways to accept failure without reducing their self-esteem or conception of ability (McCrea, 2008). Having students that are efficacious and that do not or rarely self-handicap may have positively impacted the students' grade point averages as their mean grade point average was 3.3 on a four-point scale. Furthermore, since behavior, personal factors, and the environment impact each other bidirectionally (Bandura, 1986, 1997), prior academic success and the success they are experiencing at the postsecondary level may explain why these students are efficacious and rarely exhibit self-handicapping behaviors. As a result, instructors in the Herbert College of Agriculture should challenge their students to move beyond learning factual information to developing higher-order thinking skills that are needed to solve the extraordinary challenges and opportunities our society and agriculture face today. With that in mind, future research in colleges of agriculture should determine the most effective means of challenging academically efficacious students while improving academic efficacy for those who display low academic efficacy. Furthermore, future research should determine if other populations of undergraduate agriculture students exhibit academic self-handicapping, and if they do, approaches or interventions should be investigated to determine those most effective at reducing the behavior.

Undergraduate students, in the Herbert College of Agriculture, were non-skeptical about the relevance of their schooling at the University of Tennessee for future success. Not being skeptical about the relevance of their degree program should also exert a positive influence on the undergraduate students' academic behaviors and internal personal factors and the environment of the Herbert College of Agriculture (Bandura, 1986, 1997). To that end, being future oriented directly enhances student motivation and academic performance (Eccles \& Wigfield, 1995). The fact that the students in the Herbert College of Agriculture are not skeptical about the relevance of their schooling may be the result of quality instruction within 
the college and the nationwide surplus of job opportunities and shortage of graduates in agriculture, food, and natural resources (National Research Council, 2009).

In regards to the relationship between variables under investigation in this study, the associations between academic efficacy and self-handicapping suggest students who academically self-handicap have a lower sense of academic efficacy, and students handicap at a higher rate when they are skeptical about the relevance of their degree. These associations align with Bandura's (1986) social cognitive theory, and instructors should be knowledgeable that handicapping may be an indicator of lower academic efficacy and/or skepticism about the relevance of a student's degree. Lower academic efficacy may discourage students from engaging in challenging academic tasks (Bandura, 1986; Schunk, 2012), and self-handicapping is often the result of one desiring to externalize failure (Berglas \& Jones, 1978). Therefore, if instructors recognize low academic efficacy and/or self-handicapping behaviors in their students, they may consider providing additional instructional support and ensure students are receiving high quality feedback as the aforementioned behaviors may be a result of uncertainty in the students' perception of their ability (Zuckerman \& Tsai, 2005). Future research should further investigate and seek to determine explanatory factors that influence undergraduate agriculture students' academic performance, motivation, learning strategies use, and engagement in academic task.

In conclusion, as we seek to prepare undergraduate agriculture students for the extraordinary challenges and opportunities before them, college instructors should be knowledgeable of their students' academic-related perceptions, beliefs, and strategies and use this knowledge to inform their instructional practices. Additionally, the information presented here can be used to spur dialogue and research to improve teaching and learning in colleges of agriculture.

\section{References}

Arazzini S. M., \& De George-Walker, L. (2014). Self-handicapping, perfectionism, locus of control and self-efficacy: A path model. Personality and Individual Differences, 66, 160164. https://doi.org/10.1016/j.paid.2014.03.038

Bandiera, O., Larcinese, V., \& Rasul, I. (2015). Blissful ignorance? A natural experiment on the effect of feedback on students' performance. Labour Economics, 34, 1325. https://doi.org/10.1016/j.labeco.2015.02.002

Bandura, A. (1986). Social foundations of thought and action: A social cognitive theory. Englewood Cliffs, NJ: Prentice-Hall.

Bandura, A. (1997). Self-efficacy: The exercise of control. New York, NY: W. H. Freeman and Co.

Berglas, S., \& Jones, E. (1978). Drug choice as a self-handicapping strategy in response to noncontingent success. Journal of Personality and Social Psychology, 36(4), 405417. https://doi.org/10.1037/0022-3514.36.4.405 
Davis, J. A. (1971). Elementary survey analysis. Englewood Cliffs, NJ: Prentice-Hall.

Deci, E. L., Vallerand, R. J., Pelletier, L. G., \& Ryan, R. M. (1991). Motivation and education: The self-determination perspective. Educational Psychologist, 26(3- 4), 325-346. https://doi.org/10.1080/00461520.1991.9653137

Dillman, D., Smyth, J. D., \& Christian, L. M. (2014). Internet, phone, mail, and mixed-mode surveys: The tailored design method (4th ed.). Boulevard, IN: Wiley

Eccles, J. S., \& Wigfield, A. (1995). In the mind of the actor: The structure of adolescents' achievement task values and expectancy-related beliefs. Personality \& Social Psychology Bulletin, 21(3), 215. https://doi.org/10.1177\%2F0146167295213003

Gadbois, S. A., \& Sturgeon, R. D. (2011). Academic self-handicapping: Relationships with the learning specific and general self-perceptions and academic performance over time. British Journal of Educational Psychology, 81(2), 207-222. https://doi.org/10.1348/000709910X522186

Goecker, A. D., Smith, E., Marcos Fernandez, J., Ali, R., \& Goetz, R. (2015). Employment opportunities for college graduates in food, agriculture, renewable natural resources, and the environment: United States 2015 - 2020. Retrieved from https://www.purdue.edu/usda/employment/

Herbert College of Agriculture. (2013). CASNR 2020: A Strategic Plan for the College of Agricultural Sciences and Natural Resources. Retrieved from https://ag.tennessee.edu/herbert/Documents/CASNR\%202020\%20Strategic\%20Plan.pdf

Humphreys, D., \& Davenport, A. (2005). What really matters in college: How students view and value liberal education. Liberal Education and Americas Promise, 91(3), 36-43. Retrieved from https://files.eric.ed.gov/fulltext/EJ720383.pdf

Martin, A. J., Wilson, R., Liem, A. D., \& Ginns, P. (2013). Academic momentum at university/college: Exploring the roles of prior learning, life experience, and ongoing performance in academic achievement across time. Journal of Higher Education, 84(5), 640-674. https://doi.org/10.1080/00221546.2013.11777304

McCrea, S. M. (2008). Self-handicapping, excuse making, counterfactual thinking: Consequences for self-esteem and future motivation. Journal of Personality and Social Psychology, 95(2), 174-192. https://doi.org/10.1037/0022-3514.95.2.274

Midgley, C., Kaplan, A., Middleton, M., Maehr, M., Urdan, T., Anderman, L., . . Nelson, J. (2000). Patterns of Adaptive Learning Scales. 1-74. 
Murrel, A., \& Mingone, M. (1994). Correlates of temporal perspective. Perceptual and Motor Skills, 78, 1331-1334. https://doi.org/10.2466\%2Fpms.1994.78.3c.1331

National Academies of Sciences. (2018). How people learn II: Learners, contexts, and cultures. Washington, DC: National Academies Press. https://doi.org/10.17226/24783

National Research Council. (2009). Transforming Agricultural Education for a Changing World. Washington, DC: National Academies Press.

Osterman, K. 2000. Students' need for belonging in the school community. Review of Educational Research, 70(3), 323-367. https://doi.org/10.3102\%2F00346543070003323

Pintrich, P. R., \& Zusho, A. (2007). Student motivation and self-regulated learning in the college classroom. In R. P. Perry \& J. C. Smart (Eds.), The scholarship of teaching learning in higher education (pp. 731-810). Springer, Netherlands.

Putwain, D., Sander, P., \& Larkin, D. (2013). Academic self-efficacy in study-related skills and behaviors: Relations with learning-related emotions and academic success. British Journal of Educational Psychology, 83, 633-650. https://doi.org/10.1111/j.20448279.2012.02084.x

Schunk, D. H. (2012). Learning theories: An educational perspective. Boston, MA: Pearson.

Schwinger, M., Wirthwein, L., Lemmer, G., \& Steinmayr, R. (2014). Academic Self-Handicapping and Achievement: A Meta-Analysis. Journal of Educational Psychology, 106(3), 744-761.

Stinebrickner, R., \& Stinebrickner, T. (2014). Academic Performance and College Dropout: Using Longitudinal Expectations Data to Estimate a Learning Model. Journal of Labor Economics, 32(3), 601-644. https://doi.org/10.1086/675308

Stripling, C. T., \& Ricketts, J. C. (2016). Research priority 3: Sufficient scientific and professional workforce that addresses the challenges of the 21st century. In T. G. Roberts, A. Harder, \& M. T. Brashears (Eds). American Association for Agricultural Education national research agenda: 2016-2020 (pp. 29-35). Gainesville, FL: Department of Agricultural Education and Communication.

Zuckerman, M., Kieffer, S., \& Knee, C. (1998). Consequences of self-handicapping: Effects on coping, academic performance, and adjustment. Journal of Personality And Social Psychology, 74(6), 1619-1628. https://doi.org/10.1037/0022-3514.74.6.1619

Zuckerman, M., \& Tsai, F. F. (2005). Costs of self-handicapping. Journal of Personality, 73, 411442. https://doi.org/10.1111/j.1467-6494.2005.00314.x

(C) 2020 by authors. This article is an open access article distributed under the terms and conditions of the Creative Commons Attribution license (http://creativecommons.org/licenses/by/4.0/). 